\title{
Interaction of two memory enhancing herbal drugs memory plus and mentat with morphine and imipramine in mice
}

\author{
Neera R. Gupta ${ }^{1}$, Varsha J. Patel ${ }^{2}$
}

\begin{abstract}
${ }^{1}$ Department of Medical
Education, Novo Nordisk India

Pvt Ltd, Bangalore, Karnataka, India

${ }^{2}$ Department of Pharmacology, Dr. MK Shah Medical College, Ahmedabad, Gujarat, India
\end{abstract}

Received: 12 December 2016

Revised: 15 December 2016

Accepted: 03 January 2017

*Correspondence to:

Dr. Neera R. Gupta,

Email:

drneera.gupta@gmail.com

Copyright: (c) the author(s), publisher and licensee Medip Academy. This is an openaccess article distributed under the terms of the Creative Commons Attribution NonCommercial License, which permits unrestricted noncommercial use, distribution, and reproduction in any medium, provided the original work is properly cited.

\section{ABSTRACT}

Background: The non-medical self-administration of memory enhancing drugs is a common practice. Present study was designed to evaluate interactions of two such herbal drugs- Memory plus (MP) and Mentat, with other central nervous system active drugs.

Methods: Two activities-analgesic activity and antidepressant activity were performed using adult albino mice of both sexes weighing 25-30g to observe the interactions of the herbal drugs with morphine and imipramine respectively. For each activity animals were divided into seven groups of six mice each. Group-I was control group receiving $0.2 \mathrm{ml}$ of $1 \%$ Tween $80 \mathrm{ip} / 0.2 \mathrm{ml}$ saline p.o, Group II, III and IV acute treatment groups; received single dose of herbal $(2 \mathrm{mg} / \mathrm{kg}$ ip MP or $200 \mathrm{mg} / \mathrm{kg}$ po Mentat) CNS active drugs alone in subeffective doses. Group II received morphine $2 \mathrm{mg} / \mathrm{kg}$ ip, group III imipramine $2 \mathrm{mg} / \mathrm{kg}$ ip and group IV-received MP/Mentat+ morphine or imipramine respectively. Groups $\mathrm{V}$, VI and VII were subchronic treatment groups, received drugs once daily for eight days in same dose as acute treatment groups II, III and IV respectively. Analgesic activity was measured as prolongation of reaction time by hot plate method and antidepressant activity by reduction in despair time using Porsolt's forced swimming test.

Results: When administered for 8 days, both MP and Mentat potentiated the effect of morphine preventing the development of tolerance to analgesic effect $(\mathrm{P}<0.05)$. However the antidepressant effect of imipramine was not modified by any in subchronic treatment groups.

Conclusions: Two herbal memory enhancing preparations Memory plus and Mentat potentiate analgesic effect of morphine but not the antidepressant action of imipramine in mice.

Keywords: Herb-drug interaction, Hot plate method, Imipramine, Memory enhancer/ Nootropic, Morphine, Porsolt's forced swimming test

\section{INTRODUCTION}

Traditional medicines derived from medicinal plants are used by about $60 \%$ of the world's population. ${ }^{1}$ More than $70 \%$ of India's 1.1 billion populations still use these nonallopathic systems of medicine. ${ }^{2}$ Nootropic is the term for supplements/ extracted and purified components of medicinal plants, also known as smart drugs that improve brain function. ${ }^{3}$ Memory plus (MP) contains bacosides from Bacopa monniera or "Brahmi," which has been used traditionally in the Ayurvedic system of medicine for centuries, as a brain tonic to enhance memory development, learning, and concentration, and to provide relief to patients with anxiety or epileptic disorders. ${ }^{4}$ Besides improvement in cognitive functions, MP has shown tranquilizing effects in rats and dogs, CNS depressant effect in dogs, antinociceptive and anticonvulsant effects in animal experiments. ${ }^{5-7}$ Studies have shown that nociceptive response was decreased after using Bacopa. ${ }^{6}$ Biochemical studies have shown that bacosides lead to increase in serotonin content and prevent rate of depletion of blood acetylcholine levels. ${ }^{8,9}$ 
Mentat (BR-16A) a polyherbal psychotropic preparation is claimed to enhance cognition and to ameliorate various forms of brain deficits. Of its several ingredients the important ones include Bacopa monniera for cognitive impairment, Embellica officinalis as adaptogenic and rejuvenator, Acorus calamus as sedative, analgesic and anticonvulsant, Withania somnifera as sedative and rejuvenator, Mucuna puriens as nervine tonic, Nardostachys jatamansi for insomnia, hysteria and epilepsy and Valeriana wallichi for mental disorders and epilepsy. ${ }^{10}$ In experimental studies Mentat has shown anti-nociceptive properties, antidepressant and anxiolytic properties. $^{11,12}$ The proposed mechanism of action for Mentat is by modulation of cholinergic and GABAergic neurotransmission. ${ }^{13}$ Mentat also helps to reduce the level of tribulin, an endogenous MAO inhibitor that is elevated in various levels of anxiety. ${ }^{14}$

The evidence on herb-drug interactions with these herbal preparations from experimental or clinical studies is very limited. Most often these herbal drugs are consumed as self-medication, often likely to be taken as supplement for prolonged period of time and along with other medications. This study was conducted in mice to evaluate potential of these herbal medicines to modify the action of two CNS active drugs morphine, an opioid analgesic and imipramine, a tricyclic antidepressant.
Adult albino mice of both sexes weighing 25-30 g were used for all the experiments. The animals were housed under standard conditions with natural light dark cycle and fed standard pellet feed (Amrut foods, Vaghodia, Gujarat) For each activity animals were divided into seven groups of six mice in each.

This study was approved by the Institutional Animal Ethics Committee (No./395/CPCSEA).

The test drugs used were; memory Plus powder from Nivaran herbal Pvt Ltd Madras, dispersed in 1\% Tween $80(2 \mathrm{mg} / \mathrm{kg}$, i.p) and Mentat powder from the Himalaya Drug Company Bangalore, as aqueous suspension (200mg/kg, p.o). The CNS active drugs (prototype of relevant class) were used in sub-effective doses, i.e., a dose which is substantially lower than the dose which usually produces significant activity. Morphine was used in dose of $2 \mathrm{mg} / \mathrm{kg}$ i.p and imipramine $2 \mathrm{mg} / \mathrm{kg}$ ip. For Acute Treatment Groups single dose of the drug was given and in subchronic treatment groups animals received once daily injection for eight days.

\section{Study design}

Both memory plus and mentat groups were subdivided into control, acute treatment and subchronic treatment groups for both the activities (Table 1).

\section{METHODS}

Table 1: Study design and treatment groups.

\begin{tabular}{|c|c|c|c|c|c|c|c|c|c|}
\hline \multirow{3}{*}{$\begin{array}{l}\text { Treatment } \\
\text { groups }\end{array}$} & \multirow{3}{*}{ Groups } & \multicolumn{4}{|c|}{ Eddy's hot plate method } & \multicolumn{4}{|c|}{ Porsolt's forced swimming test } \\
\hline & & \multicolumn{2}{|c|}{ Memory plus groups } & \multicolumn{2}{|c|}{ Mentat groups } & \multicolumn{2}{|c|}{ Memory plus groups } & \multicolumn{2}{|l|}{ Mentat groups } \\
\hline & & Drug (i.p) & $\begin{array}{l}\text { Dose } \\
\mathrm{mg} / \mathrm{kg}\end{array}$ & Drug & $\begin{array}{l}\text { Dose } \\
\mathrm{mg} / \mathrm{kg}\end{array}$ & Drug (i.p) & $\begin{array}{l}\text { Dose } \\
\mathrm{mg} / \mathrm{kg}\end{array}$ & Drug & $\begin{array}{l}\text { Dose } \\
\mathrm{mg} / \mathrm{kg}\end{array}$ \\
\hline Control & Gr I & $\begin{array}{l}1 \% \text { Tween } \\
80\end{array}$ & $0.2 \mathrm{ml}$ & Saline p.o & $0.2 \mathrm{ml}$ & $1 \%$ Tween 80 & $0.2 \mathrm{ml}$ & Saline p.o & $0.2 \mathrm{ml}$ \\
\hline \multirow{3}{*}{$\begin{array}{l}\text { Acute } \\
\text { treatment } \\
\text { groups } \\
\text { single dose) }\end{array}$} & Gr II & MP & 2 & Mentat p.o & 200 & MP & 2 & Mentat p.o & 200 \\
\hline & Gr III & Morphine & 2 & Morphine i.p & 2 & Imipramine & 2 & $\begin{array}{l}\text { Imipramine } \\
\text { i.p }\end{array}$ & 2 \\
\hline & Gr IV & $\begin{array}{l}\text { MP+ } \\
\text { Morphine }\end{array}$ & $2+2$ & $\begin{array}{l}\text { Mentat p.o + } \\
\text { Morphine i.p }\end{array}$ & $200+2$ & $\begin{array}{l}\mathrm{MP}+ \\
\text { Imipramine }\end{array}$ & $2+2$ & $\begin{array}{l}\text { Mentat p.o+ } \\
\text { Imipramine } \\
\text { i.p }\end{array}$ & 2002 \\
\hline \multirow{3}{*}{$\begin{array}{l}\text { Subchronic } \\
\text { treatment } \\
\text { groups } \\
\text { (once daily } \\
\text { for eight } \\
\text { days) }\end{array}$} & Gr V & MP & 2 & Mentat p.o & 200 & MP & 2 & Mentat p.o & 200 \\
\hline & Gr VI & Morphine & 2 & Morphinei.p & 2 & Imipramine & 2 & Imipraminei.p & 2 \\
\hline & Gr VII & $\begin{array}{l}\text { MP+ } \\
\text { Morphine }\end{array}$ & $2+2$ & $\begin{array}{l}\text { Mentat p.o+ } \\
\text { Morphinei.p }\end{array}$ & $200+2$ & $\begin{array}{l}\mathrm{MP}+ \\
\text { Imipramine }\end{array}$ & $2+2$ & $\begin{array}{l}\text { Mentat p.o+ } \\
\text { Imipraminei.p }\end{array}$ & $200+2$ \\
\hline
\end{tabular}

\section{Analgesic activity by Eddy's hot plate method ${ }^{15}$}

The hot plate method of Eddy and Leimbach 1953 as modified by Woolfe and Macdonald was used. Eddy's hot plate (Techno laboratories, Lucknow) was used and prolongation of reaction time was the end point. Temperature of the plate was maintained at $55.5 \pm 0.5^{0} \mathrm{c}$.
Animals were screened by keeping each of them on the hot plate. Animals with reaction time less than 12 seconds were selected. Each animal was kept on hot plate 30 minutes after injecting the drug and reaction time i.e. time taken by the animal for licking its hind paw, was measured in seconds. 30 seconds interval was considered as cut off time to avoid heat induced injury to the animal. 
Reaction time was expressed in seconds as mean \pm SEM. The test was carried out on day 1 and was repeated on day 8 in Subchronic treatment groups.

\section{Antidepressant activity by Porsolt's forced swimming test $^{16}$}

The activity was based on method described by Porsolt et al. Briefly animals were forced to swim individually for 15 minutes in a glass container $(11 \mathrm{~cm}$ diameter and 15 $\mathrm{cm}$ height) containing fresh water upto a height of $6 \mathrm{~cm}$ at a temperature of $22 \pm 1^{0} \mathrm{c}$. This constituted the pretest session. 24 hours later the test session was held. In test session 30 minutes after the administration of drug the animals were forced to swim in a similar environment as in pre-test session for a period of 5 minutes. The animal attempts to get out of the beaker were interspersed with periods of immobility signifying "behavioural despair". The total duration of immobility during the last 4 minutes of the 5 minutes test was recorded. Despair time was measured in seconds i.e. total period of immobility in last 4 minutes. The test was carried out on day 1 and was repeated on day 8 in subchronic treatment groups. The despair time was expressed as mean+SEM.

\section{Statistical analysis}

The values were expressed as mean+SEM. Results for analgesic and antidepressant activity were statistically analysed by using one way analysis of variance (ANOVA) and Post ANOVA Tukey's multiple range test was used to define the significant difference $(p<0.05)$.

\section{RESULTS}

\section{Analgesic activity}

Acute treatment groups

Acute treatment with memory plus or Mentat alone did not show significant analgesic effect as measured by reaction time. Acute treatment with sub-effective dose of morphine alone showed significant prolongation of reaction time in one group compared with controls. Single dose treatment with combination of Memory plus and morphine did not show significant prolongation of reaction time while single dose of Mentat and morphine showed significant prolongation of reaction time (Table 2).

Table 2: Effect of memory plus and mentat on reaction time when used alone or in combination with morphine.

\begin{tabular}{|c|c|c|c|c|c|c|}
\hline \multicolumn{4}{|c|}{$\begin{array}{l}\text { Memory Plus Groups } \\
\text { (N=6 in each group) }\end{array}$} & \multicolumn{3}{|c|}{$\begin{array}{l}\text { Mentat Groups } \\
(\mathrm{N}=6 \text { in each group) }\end{array}$} \\
\hline \multicolumn{2}{|l|}{ Treatment groups } & $\begin{array}{l}\text { Dose } \\
\text { Mg/kg } \\
\text { i.p }\end{array}$ & $\begin{array}{l}\text { Reaction time } \\
\text { in seconds } \\
\text { Mean } \pm \text { SEM }\end{array}$ & $\begin{array}{l}\text { Treatment } \\
\text { groups }\end{array}$ & $\begin{array}{l}\text { Dose } \\
\text { Mg/kg }\end{array}$ & $\begin{array}{l}\text { Reaction time in } \\
\text { seconds } \\
\text { Mean } \pm \text { SEM }\end{array}$ \\
\hline Control & $1 \%$ Tween 80 & $0.2 \mathrm{ml}$ & $7.66 \pm 1.4$ & Saline p.o & $0.2 \mathrm{ml}$ & $7.5 \pm 0.6$ \\
\hline \multirow{3}{*}{$\begin{array}{l}\text { Acute Treatment } \\
\text { Groups } \\
\text { (Single dose) }\end{array}$} & MP & 2 & $10.16 \pm 2.2$ & Mentat p.o & 200 & $13.2 \pm 1.8$ \\
\hline & Morphine & 2 & $16.16 \pm 2.9^{\#}$ & Morphine i.p & 2 & $16.16 \pm 2.9$ \\
\hline & MP+Morphine & $2+2$ & $13.33 \pm 1.9$ & $\begin{array}{l}\text { Mentat p.o+ } \\
\text { Morphine i.p }\end{array}$ & $200+2$ & $18.6 \pm 3.3^{\#}$ \\
\hline \multirow{3}{*}{$\begin{array}{l}\text { Subchronic } \\
\text { Treatment Groups } \\
\text { (Once daily for } 8 \\
\text { days) }\end{array}$} & MP & 2 & $16 \pm 2.7^{\#}$ & Mentat p.o & 200 & $15.1 \pm 2.1$ \\
\hline & Morphine & 2 & $10.16 \pm 2.3$ & Morphine i.p & 2 & $10.16 \pm 2.3$ \\
\hline & MP+Morphine & $2+2$ & $16.83 \pm 2.0^{\#}$ & $\begin{array}{l}\text { Mentat p.o+ } \\
\text { Morphine i.p }\end{array}$ & $200+2$ & $19.8 \pm 4.5^{\#}$ \\
\hline \multicolumn{4}{|l|}{ F 6.1} & \multicolumn{3}{|l|}{ F 2.56} \\
\hline \multicolumn{4}{|l|}{ df 6,35} & \multicolumn{3}{|l|}{ df 6,35} \\
\hline \multirow{2}{*}{\multicolumn{4}{|c|}{$\begin{array}{l}\text { Difference of Mean } 7.9 \\
\text { Post ANOVA TUKEY's Test }\end{array}$}} & \multirow{2}{*}{\multicolumn{3}{|c|}{$\begin{array}{l}\text { Difference of Mean } 11.9 \\
\text { Post ANOVA TUKEY's Test }\end{array}$}} \\
\hline & & & & & & \\
\hline \multicolumn{4}{|c|}{${ }^{\#} \mathrm{P}<0.05$ Vs Control } & \multicolumn{3}{|c|}{${ }^{\#} \mathrm{P}<0.05$ Vs Control } \\
\hline
\end{tabular}

\section{Subchronic treatment groups}

Subchronic treatment with memory plus alone showed significant prolongation of reaction time while subchronic treatment of Mentat did not show significant prolongation of reaction time. Subchronic treatment with sub-effective dose of morphine alone did not show significant prolongation of reaction time. Subchronic treatment with combination of Memory plus and morphine or Mentat and morphine, showed significant prolongation of reaction time $(\mathrm{P}<0.05)$ (Table 2$)$.

\section{Antidepressant activity}

Acute treatment groups

Single dose of memory plus or Mentat alone did not show significant reduction in despair time compared to control group. Acute treatment with imipramine alone in sub 
effective showed significant reduction in despair time in one group compared with controls. Acute treatment with combination of Memory plus and imipramine or Mentat and imipramine showed significant reduction in despair time compared with control group but not significant compared with imipramine alone (Table 3 ).

\section{Subchronic treatment groups}

Subchronic treatment with memory plus or Mentat alone, did not show significant reduction in despair time. Subchronic treatment with imipramine alone in sub effective dose showed significant reduction in despair time. Subchronic treatment with combination of Memory plus and imipramine or Mentat with imipramine showed significant reduction in despair time compared to controls $(\mathrm{P}<0.05)$, no significant difference was observed between subchronic combination groups and subchronic imipramine alone (Table 3).

Table 3: Effect of memory plus and mentat on despair time when used alone or in combination with imipramine.

\begin{tabular}{|c|c|c|c|c|c|c|}
\hline \multicolumn{4}{|c|}{$\begin{array}{l}\text { Memory Plus Groups } \\
\text { (N=6 in each group) }\end{array}$} & \multicolumn{3}{|c|}{$\begin{array}{l}\text { Mentat Groups } \\
\text { (N=6 in each group) }\end{array}$} \\
\hline \multicolumn{2}{|l|}{ Treatment Groups } & $\begin{array}{l}\text { Dose } \\
\text { Mg/kg } \\
\text { i.p }\end{array}$ & $\begin{array}{l}\text { Despair time in } \\
\text { seconds } \\
\text { Mean } \pm \text { SEM }\end{array}$ & $\begin{array}{l}\text { Treatment } \\
\text { groups }\end{array}$ & $\begin{array}{l}\text { Dose } \\
\mathrm{Mg} / \mathrm{kg}\end{array}$ & $\begin{array}{l}\text { Despair time in } \\
\text { seconds } \\
\text { Mean } \pm \text { SEM }\end{array}$ \\
\hline Control & $1 \%$ Tween 80 & $0.2 \mathrm{ml}$ & $151 \pm 19$ & Saline p.o & $0.2 \mathrm{ml}$ & $164+2 \overline{1}$ \\
\hline \multirow{3}{*}{$\begin{array}{l}\text { Acute Treatment } \\
\text { Groups } \\
\text { (Single dose) }\end{array}$} & MP & 2 & $93 \pm 27$ & Mentat p.o & 200 & $101 \pm 14$ \\
\hline & Imipramine & 2 & $73 \pm 25$ & Imipraminei.p & 2 & $73 \pm 25^{\#}$ \\
\hline & $\begin{array}{l}\text { MP+ } \\
\text { Imipramine }\end{array}$ & $2+2$ & $53 \pm 15^{\#}$ & $\begin{array}{l}\text { Mentat p.o+ } \\
\text { Imipramine i.p }\end{array}$ & $200+2$ & $72 \pm 19^{\#}$ \\
\hline \multirow{3}{*}{$\begin{array}{l}\text { Subchronic } \\
\text { Treatment Groups } \\
\text { (Once daily for } 8 \\
\text { days) }\end{array}$} & MP & 2 & $123 \pm 30$ & Mentat p.o & 200 & $109 \pm 13$ \\
\hline & Imipramine & 2 & $37 \pm 12^{\#}$ & Imipramine i.p & 2 & $37 \pm 12^{\#}$ \\
\hline & $\begin{array}{l}\mathrm{MP+} \\
\text { Imipramine }\end{array}$ & $2+2$ & $29 \pm 15^{\#}$ & $\begin{array}{l}\text { Mentat p.o+ } \\
\text { Imipramine i.p }\end{array}$ & $200+2$ & $53 \pm 16^{\#}$ \\
\hline \multicolumn{4}{|l|}{ F 4.8} & \multicolumn{3}{|l|}{ F 5.3} \\
\hline \multicolumn{4}{|l|}{ df 6,35} & \multicolumn{3}{|l|}{ df 6,35} \\
\hline \multirow{2}{*}{\multicolumn{4}{|c|}{$\begin{array}{l}\text { Difference of Mean } 84 \\
\text { Post ANOVA TUKEY's Test }\end{array}$}} & \multirow{2}{*}{\multicolumn{3}{|c|}{$\begin{array}{l}\text { Difference of Mean } 79 \\
\text { Post ANOVA TUKEY's Test }\end{array}$}} \\
\hline & & & & & & \\
\hline \multicolumn{4}{|c|}{${ }^{\#} \mathrm{P}<0.05$ Vs Control } & \multicolumn{3}{|c|}{${ }^{\#} \mathrm{P}<0.05$ Vs Control } \\
\hline
\end{tabular}

\section{DISCUSSION}

Herb-drug interactions between herbal medicines and prescribed drugs have been reported in some studies. Patients with chronic diseases and psychiatric disorders use an array of herbal medicines and more likely to face adverse concerns of herb-drug interactions. A study by Bender J Kenneth has reported that herbal medicines do pose potential for herb-drug interactions. ${ }^{13}$ In one study by Malhotra et al analgesic effects of Bacopa monneira were manifested by the doses which were toxic to the rats. ${ }^{17}$ Another study reported that the nociceptive response is decreased after using Bacopa. ${ }^{18}$ Mentat on repeated administration for 9 days has also shown to attenuate the development of tolerance to the analgesic response of morphine in mice. ${ }^{11}$

In present study memory plus on subchronic treatment has shown significant analgesia while Mentat alone on subchronic treatment did not. Morphine even in subeffective dose produced significant analgesia in acute treatment group and analgesic response was lost on subchronic administration of morphine, possibly due to development of tolerance to analgesic response. When morphine was given in combination with either Memory Plus or Mentat in subchronic treatment groups, significant analgesic activity was maintained. The results suggest that co-administration of Memory Plus with morphine or Mentat with morphine can attenuate the development of tolerance to analgesic effect of morphine. The results support the findings of study by Kulkarni et al. $^{11}$

Study by Gupta et al suggested the use of Bacopa for the treatment of anxiety and depression along with improving the capacity to learn and remember. ${ }^{19}$ Bhattacharya et al reported that Mentat $(100 \mathrm{mg} / \mathrm{kg}$ po) has been reported to exhibit significant antidepressant effect as indicated by its ability to reduce swim stress induced immobility in Porsolt's behavioural despair test in mice, reduction in escape failures concomitant with an increase in avoidance response in the learned helplessness, suggestive of its possible clinical utility as an adjuvant in treatment of anxiety and depression. ${ }^{20}$

Present study has shown that either memory plus or Mentat on acute or subchronic treatment did not produce significant antidepressant activity as measured by despair 
time in Porsolt's forced swim stress test. The sub effective dose of imipramine in combination with either MP or Mentat in acute treatment groups produced significant antidepressant activity. While in subchronic treatment interaction study Memory Plus with imipramine or Mentat with imipramine did not modify antidepressant effect of imipramine. Memory Plus or Mentat possibly could be useful as an adjuvant to antidepressant drugs for their properties to prevent adverse effects associated with antidepressant drugs like sedation and cognitive impairment, without contributing to antidepressant effects.

These findings that both memory plus containing bacosides and Mentat, a multi-ingredient preparation containing Bacopa monneira and several other plants as active ingredients have potential to modify the actions of drugs acting on central nervous system like morphine but not imipramine. The result of these interactions could be beneficial when used concurrently with analgesics or antidepressants provided there is no enhancement of adverse reactions. On the other hand these interactions are likely to increase the severity and/or frequency of adverse reactions.

\section{CONCLUSION}

To conclude, our study on mice demonstrates that Memory plus and Mentat potentiate the activity of centrally active drugs like morphine and may act as an adjuvant to imipramine which may result in synergistic effects in terms of preventing the tolerance to analgesic effect of morphine and guarding the side effects associated with antidepressants like sedation and cognitive impairment. However, this is preliminary experimental data, further clinical studies are necessary to explore the interaction in healthy humans or patients treated with analgesics or antidepressants who may selfmedicate with these herbal remedies.

Funding: No funding sources Conflict of interest: None declared

Ethical approval: The study was approved by the Institutional Animal Ethics Committee

\section{REFERENCES}

1. Modak M, Dixit P, Londhe J. Indian Herbs and Herbal Drugs Used for the Treatment of Diabetes. J Clin Biochem Nutr. 2007;40(3):163-73.

2. Vaidya ADB, Devasagayam TPA. Current Status of Herbal Drugs in India: An Overview. J Clin Biochem Nutr. 2007;41(1):1-11.

3. Houghton PJ, Raman A. Laboratory handbook for fractionation of natural extracts. London: Chapman and Hall; 1998:199.

4. Chopra RN. Indigenous Drugs of India. 2nd ed. Calcutta, India: U.N. Dhur and Sons; 1958:341.
5. Malhotra CL, Das PK, Dhalla NS. Investigations on mechanism of barbiturate hypnosis by hersaponin, acorus oil, reserpine, chlorpromazine. Arch Phar (Weinheim). 1962;295-537.

6. Gupta SS. A few observations on the psychotropic and anticonvulsant effects of same ayurvedic remedies. Indian Journal of Physiology and Pharmacology. 1962;6-25.

7. Vohra D, Pal SN. Effect of locomotor activity on passive avoidance test for evaluation of cognitive function. Indian Journal of Pharmacology. 2000;32:242-5.

8. Dey PK, Datta C. Effect of Psychotropic phytochemicals on cerebral amino acid levels in mice. Indian Journal of Experimental Biology. 1996;4:216-9.

9. Tripathi YB, Chaurasia S. Bacopa Monniera as an antioxidant Mechanism of action. Indian Journal of Experimental Biology. 1996;34:523-6.

10. The Himalaya Company, Mentat- A Product Monograph; 2001.

11. Kulkarni SK, Verma A. Prevention of development of tolerance and dependence to opiate in mice by Mentat, a herbal psychotropic preparation. Indian Journal of Experimental Biology. 1992;30:885-8.

12. Izzo AA, Ernst E. Interactions between herbal medicines and prescribed drugs. Drugs. 2001;61(15):2163-3173.

13. Kenneth BJ. Herbal Medicines pose potential drug interaction hazard. Psychiatric Times. 1998;XV(8).

14. Kulkarni SK, Verma A. Mentat; herbal preparation improves learning and memory performance in mice. Indian Drugs. 1993;(30)3:97.

15. Eddy NB, Leimback B. Synthetic analgesics: 11 Dithyienylbutenylamines and dithyienylbuttylamines. J. Pharmgcol Exp.1953;3:544-7.

16. Porsolt RD, Berlin A, Jalpre M. Behavioural despair in mice. A preliminary screening test for antidepressants. Arch Int. Pharmacodynamics Ther. 1977;239:327-36.

17. Malhotra CL, Das PK. Pharmacological Studies of Herpestis Monniera (Brahmi). Indian Journal of Medical Research. 1959;47:3.

18. Martis G, Rao A, Karanth KS. Neuropharmacological activity of Herpestis Monniera. Fetoterapia. 1992;5:399-404.

19. Gupta SS. A few observations on the psychotropic and anticonvulsant effects of some Ayurvedic remedies. Indian Journal of Physiology and Pharmacology. 1962;6:25.

20. Bhattacharya SK. Behavioural studies on Mentat, a herbal psychotropic formulation. Indian Journal Experimental Biology. 1994;32:37-43.

Cite this article as: Gupta NR, Patel VJ. Interaction of two memory enhancing herbal drugs memory plus and mentat with morphine and imipramine in mice. Int J Basic Clin Pharmacol 2017;6:427-31. 